\section{University of California Cooperative Extension Processing Tomato Cultivar Evaluation Program}

\author{
M ike M urray, ${ }^{1} \mathrm{M}$ ike C ahn, \\ Janet Caprile, D on M ay, \\ Gene M iyao, Bob M ullen, \\ Jesus Valencia, and Bill Weir
}

ADdiTIONAL INDEX WORDS. plant breeding, technology transfer, L ycopersicum esculentum

Summary. U niversity of California C ooperative Extension farm advisors have conducted applied research to quantify processing tomato

[Lycopersicum esculentum (L.) M ill] varietal performance, as a coordinated activity, since 1973. E arly and midseason maturity varieties are annually evaluated at four to six locations throughout the state. The test varieties are selected in collaboration with seed companies, processors and growers. The growers and seed companies provide financial support for the tests. M ost tests are conducted in production tomato fields and are harvested using commercial harvesters. The results are widely disseminated through an annual report to the funding sources, farm advisor research reports, newsletters, production meetings, the $\mathrm{C}$ alifornia Tomato Grower magazine, and popular media. The information obtained for fruit yield potential, fruit quality and plant horticultural characteristics is used by processors, growers, and seed compa-

Farm advisors, U niversity of California Cooperative Extension, Colusa, Sutter/ Yuba, C ontraC osta, Fresno, Yolo/ Solano, San Joaquin, Stanislaus, and Merced Counties, respectively.

The cost of publishing this paper was defrayed in part by the payment of page charges. U nder postal regulations, this paper therefore must be hereby marked advertisement solely to indicate this fact.

${ }^{1} T$ o whom reprint requests should be addressed: $P .0$ Box 180, Colusa, CA 95932; mmurray@usdavis.edu. nies to make variety selection decisions. This regional extension program has proven to be an effective way to generate well-designed replicated information for making intelligent processing tomato cultivar decisions and has been well accepted by the California industry.

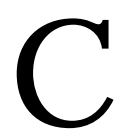

alifornia leads the U nited States in the production of processing tomatoes. M ore than 260,000 acres $(105,000 \mathrm{ha})$ of processing tomatoes were grown in California in 1997, resulting in $>10.6$ million tons (9.6 million $\mathrm{t}$ ) of fruit being produced (California Agricultural Statistics Service, 1998). This was $92 \%$ of the total U.S. processing tomato acreage and $94 \%$ of the fruit production. The average yield of 38.2 tons/ acre $\left(85.7 \mathrm{t} \cdot \mathrm{ha}^{-1}\right)$ wasthehighest in the U nited States (C alifornia Agricultural Statistical Services, 1998). The California processing tomato crop had a total on-farm value of $\$ 608$ million in 1996, making it the single highest value processing vegetable crop produced in the state (California Agricultural Statistical Services, 1997).

The key word in California agriculture is diversity, which would be expected in a state that stretches 1000 miles $(1610 \mathrm{~km})$ between the $M$ exican and $O$ regon borders. $D$ ifferences in climate, soil texture, soil quality and local production practices are significant and impact performance of each variety differently. Tomato production in California occurs from the I $\mathrm{m}$ perial Valley (latitude $32 \mathrm{~N}$ ) to Colusa (latitude $39 \mathrm{~N}$ ) and from the central coastal regions to the San J oaquin and

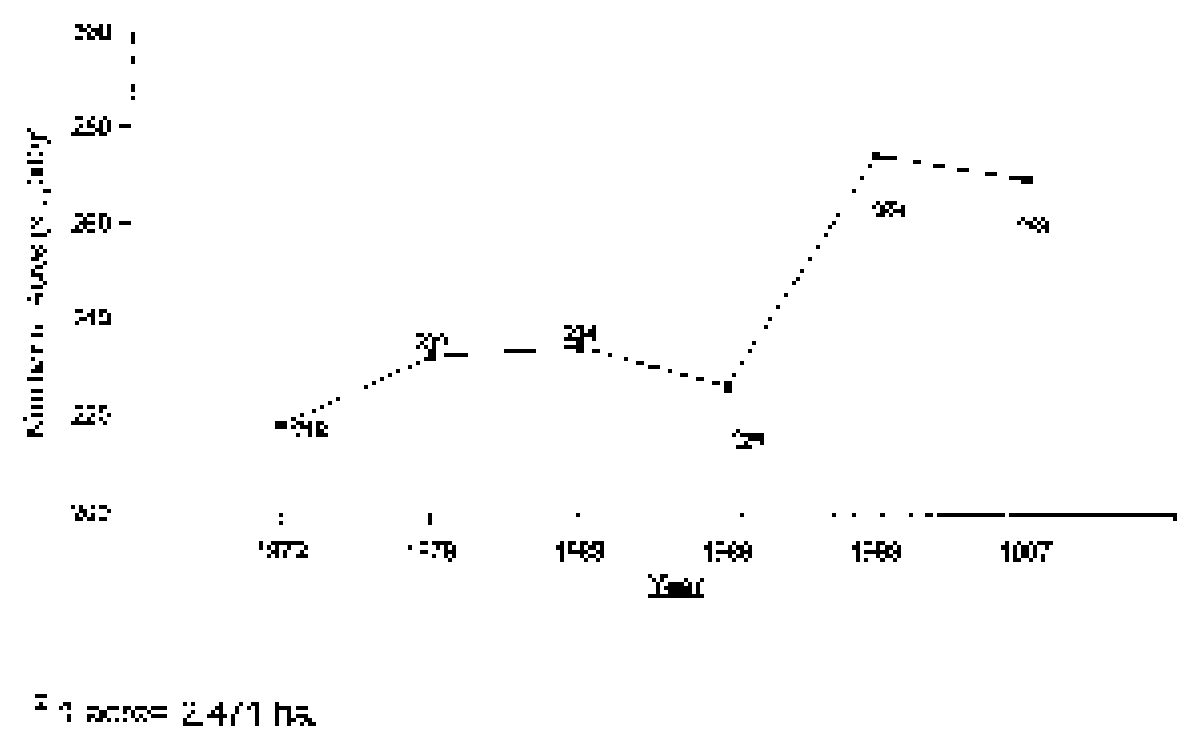

Sacramento V alley interiors. These areas differ in rainfall, maximum and minimum air temperatures, soil types and fertility, and water quality and availability. This suggests that some regions would be better suited for specific varieties or final processing tomato products.

M ore than 175 different processing tomato varieties were commercially produced in California in 1997. The counties leading production were Fresno (36\%), Yolo (19\%), SanJ oaquin (10\%), Colusa ( $8 \%)$, and Sutter, Solano, Stanislaus, and M erced (4\%to 6\%each). Collectively, these eight counties accounted for $>93 \%$ of the entire crop (California Agricultural Statistics Service, 1998). Thevarieties'H alley 3155’ and ' $\mathrm{H}$ einz 8892 ' represented $>48 \%$ of thetotal production (Rivara, 1997). An additional 48 additional varieties, however, made up the bulk of the remaining delivered harvest (45\%), illustrating the need for a coordinated neutral effort to sort through the array of varietal choices.

A program was initiated in 1973 to address this need. Farm advisors from Fresno, San Joaquin, and Yolo Counties banded together to conduct the first cooperative processing tomato variety evaluation. At that time, most of the state's production was located in thosethreeareas. Since then, theindustry has expanded, taking advantage of environmental niches, spreading therisk of crop failureacrossgreater acreageand providing additional optionsfor tomato rotation. Today, farm advisors in six to

Fig. 1. H arvested acreage of processing tomatoes in C alifornia, 1973-97. 
$\pm i$

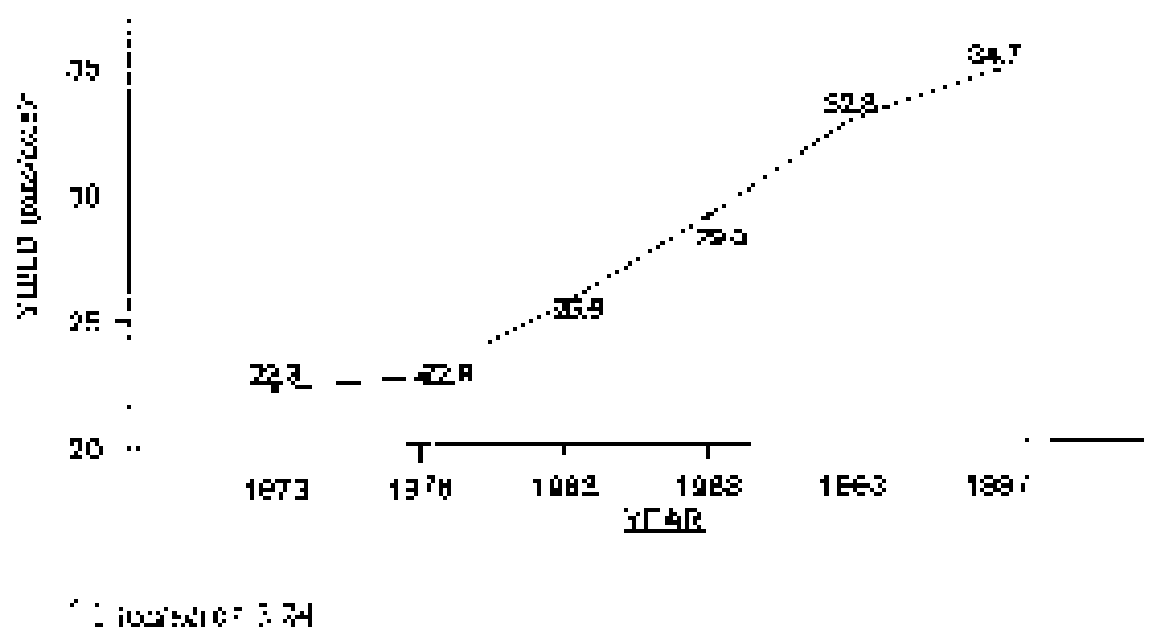

Fig. 2. Average processing tomato yields in C alifornia, 1973-97.

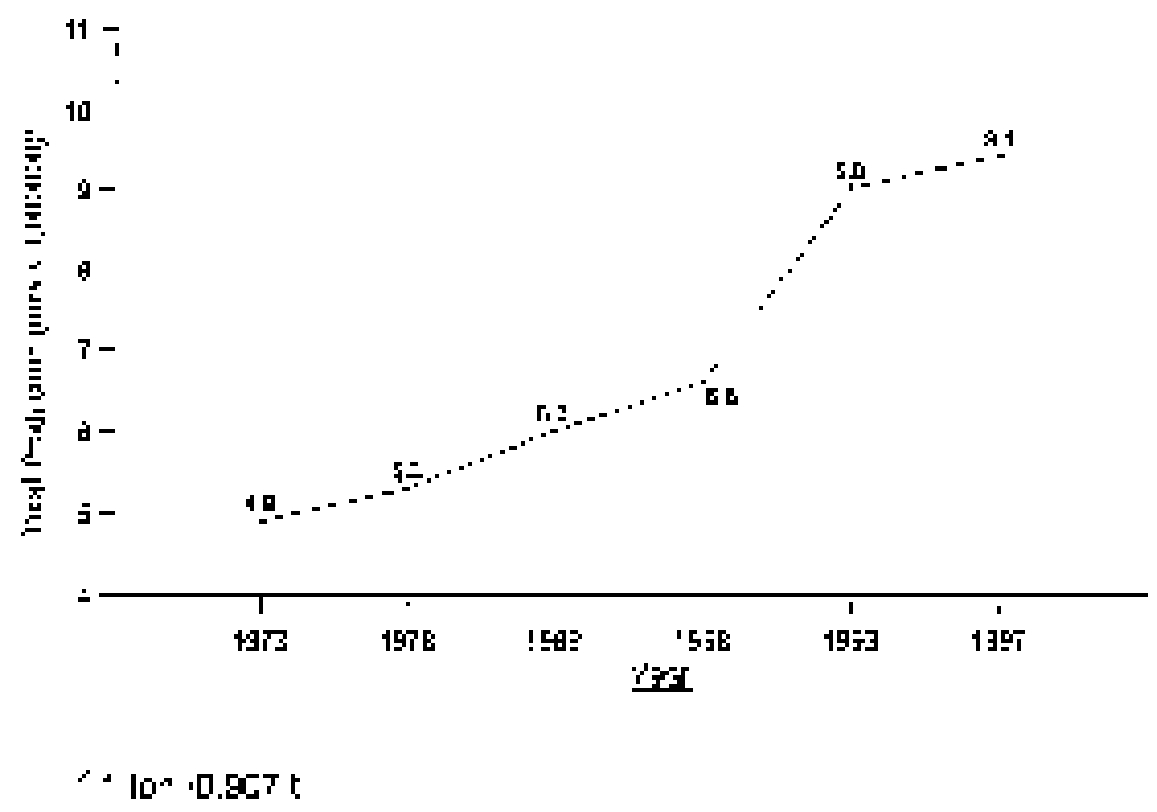

Fig. 3. T otal C alifornia processing tomato production, 1973-97.

eight of the major production areas conduct annual variety evaluations. Figures 1 through 3 illustrate how the California processing tomato industry has changed during the time period of this statewide evaluation program.

\section{Materials and methods}

Overvew. The objective of the University of California (UC) Statewide Processing $T$ omato $V$ ariety Evaluation Trials is to evaluate a common group of new or recently released varieties, under uniform methods, in multilocations. Separate tests are conducted for both early maturity and mid years, unless there are compelling reasons to extend the evaluation period. Thetestsal so include two industry standards, selected on the basis of previous trial data.

Varietal selection. The test varieties are selected after extensive discussionsand interactionswith theindustry. These discussions begin in the late fall, with a meeting of the $U C$ researchers and commercial processor managers. The results of the previous year's trial program are reviewed. Advice on which varietiesto continuein the program and which to drop is given, based on each processor's raw product needs and the regional performances of each variety. Processors also identify additional varieties to test, from preliminary information received from seed companies or from their own internal variety evaluations.

The $\mathrm{U} C$ researchers communicate with seed companies operating in California and share the results of the processor discussions. Seed availability for desired varieties is determined and the seed companies suggest additional varietiesfor testing that were not previously identified by the processors.

Project funding. There are two sources of funding for this work. The first is an annual grant from the California Tomato Research Institute, Inc. (CTRI). This grower group voluntarily assesses itself to generate monies to support applied research in processing tomatoes. Theycontributeabout $\$ 6,000$ to the project annually. Themoney pays for fruit samples, obtained from each variety at each location, to be analyzed for soluble solids and juice color by the grading stations of the Processing Tomato Advisory Board. CTRI also provides periodic funding for the construction or maintenance of special ized equipment used to obtain fruit yield data.

The second source of funding is provided by participating seed companies. An entry fee of $\$ 100$ per replicated variety and $\$ 50$ per observational variety is requested for each test location. This money is provided to the farm advisors conducting tests and is used to hiretemporary field assistance, purchase materials and equipment, and support travel associated with developing or delivering trial information.

Although no actual monieschange hands, the cooperating growers also provide significant support by providing test sites, equipment and crop management. They also accommodate data 
T able 1. U niversity of $C$ alifornia farm advisor early maturity 1997 processing tomato variety trial data for replicated varieties. Combined data from five locations (C olusa, Fresno, San J oaquin, Stanislaus, and Yolo C ounties).

\begin{tabular}{|c|c|c|c|c|}
\hline Variety & $\begin{array}{c}\text { Yield } \\
\text { (tons/acre) }\end{array}$ & ${ }^{\circ} \mathrm{Brix}^{\mathrm{y}}$ & $\begin{array}{c}{ }^{\circ} B \text { rix } \times \\
\text { yield } \\
\text { (tons/acre) }\end{array}$ & $\begin{array}{c}\text { B lended } \\
\text { juice } \\
\text { color }^{\mathrm{w}}\end{array}$ \\
\hline CXD 171 & 45.8 & 5.2 & 2.37 & 25.1 \\
\hline Sun 6235 & 45.7 & 5.0 & 2.28 & 24.9 \\
\hline Red-Set-Go 28 & 44.9 & 4.5 & 2.02 & 25.0 \\
\hline H $3044^{v}$ & 43.5 & 4.3 & 1.87 & 23.4 \\
\hline BOS 8066 & 43.4 & 4.3 & 1.86 & 24.3 \\
\hline RPT 1108 & 43.2 & 4.7 & 2.03 & 26.4 \\
\hline APT 266 & 41.9 & 5.1 & 2.14 & 24.4 \\
\hline FMX $1071 \mathrm{~N}$ & 41.9 & 4.6 & 1.93 & 26.9 \\
\hline PX 16313 & 41.9 & 4.7 & 1.97 & 27.5 \\
\hline CXD 187 & 41.7 & 4.6 & 1.92 & 24.2 \\
\hline H yPeel 45 & 41.0 & 5.4 & 2.21 & 25.8 \\
\hline АРТ X 410 & 40.8 & 4.9 & 2.00 & 23.8 \\
\hline Sun 6117 & 40.3 & 5.0 & 2.02 & 24.8 \\
\hline $\mathrm{FM} \times 1080 \mathrm{~N}$ & 40.0 & 4.7 & 1.86 & 26.9 \\
\hline H $9280^{\circ}$ & 36.2 & 4.2 & 1.52 & 23.8 \\
\hline LSD & 3.3 & 0.2 & 0.18 & 1.0 \\
\hline CV $(\%)$ & 10.5 & 6.0 & 12.1 & 6.1 \\
\hline M ean & 42.1 & 4.7 & 1.99 & 25.1 \\
\hline Variety $\times$ location $\left(\mathrm{LSD}_{0.05}\right)$ & 13.7 & 0.4 & 0.7 & NS \\
\hline
\end{tabular}

w1 ton/ acre $=2.24 \mathrm{t} \cdot \mathrm{ha}^{-1}$.

xpercent soluble solids. Composite fruit sample, mixed in a blender under vacuum.

yYield $\times{ }^{\circ}$ Brix, 1 ton/ acre $=2.24 \mathrm{t} \cdot \mathrm{ha}^{-1}$

${ }^{z}$ Composite fruit sample, mixed in a blender under vacuum. The lower values are more intense red than larger values.

vStandard varieties.

${ }^{\mathrm{N}} \mathrm{N}$ onsignificant.

collection by facilitating harvest schedule slowdowns. Processors, in turn, cooperate by accepting loads of mixed fruit.

Planting the tests. The test sites are approximately one acre in size and are located within larger production fields. Plots $100 \mathrm{ft}(30 \mathrm{~m})$ long are typically used at each site. E very attempt is made to treat each site uniformly across locations. Fresh, viable seed lots are obtained from the seed companies and sublots are sent to each location advisor. Seed weights are obtained, and approximatelythesamenumber of seeds are planted in each plot at each site. The cooperating grower plants the entire field with his equipment, except for study plots. I n thepremarked plot areas, the planter chains are disconnected and the planters apply preplant fertilizer to the plots without dropping seed. $U$ sing the marks left by the planter packing wheel to indicate row placement, the plots are then seeded at an appropriate soil depth with a hand-push planter. 0 ther than planting and harvesting, all of thecultural operationsare conducted by the grower and are the same as the larger production field. $\mathrm{N}$ otes are taken during the growing season by the location advisor and include: emergence dates, final plant stands, seedling vigor, and growing conditions. Varietal differences for disease resistance or tolerance are also recorded.

SAMPLING THE FRUIT. The plots are sampled 1 to $3 \mathrm{~d}$ before the field being harvested. All of the fruit are removed from several randomly selected plants in each plot. Fruit are separated into red, green immature, and cull categories. These categories are weighed to obtain fruit maturity information. A sample of 30 to 50 marketable fruit [5.5 to $6.5 \mathrm{lb}(2.5$ to $3.0 \mathrm{~kg})$ depending on fruit size] is taken to a state grading station for soluble solids and color determinations. All loads delivered to processors must go through a privately operated station to pass inspection requirements and determine baseline fruit quality information. Soluble solids are determined with a temperature-compensated, hand-held, refractometer (model 10423; American O ptical Corp.). Color determinations are made with a LED tomato color meter developed by the UC, Davis, Biological and Agricultural Engineering Department.

Harvesting the plots. Test sites are harvested at the sametimeastherest of the larger production field, using the grower's harvester and crew. The 100foot-long plotsare harvested and all the fruit on the belts and chains are run through the machine. The harvester is stopped at the end of each plot and the fruit is routed into a hydraulic dumper gondola equipped with load sensing bars. A digital read out of the weight is obtained and fruit yields per acre are calculated. The harvest trailer gondolas have a capacity of 8,000 to $10,000 \mathrm{lb}$ $(3,625$ to $4,535 \mathrm{~kg})$ of fruit, so they must be periodically emptied into commercial bulk trailersas harvest of the test proceeds. The harvest trailers were provided to the farm advisors with funding from the CTRI. The quality and quantity of the fruit from the plots should approximatethereal-world situation, as a commercial harvester and crew are used.

Analyzing the data. A biometrician is contracted to analyze the data from the varioustest sites. The data are evaluated for main effects of the variety, site or location effects and interactions of locations and varieties.

Reporting the Results. I nformation from the statewide trials is extended to end-users in a variety of ways. First, field days are held at the test sites within 2 to 3 weeks of harvest. G rowers, 
T able 2. U niversity of C alifornia farm advisor midmaturity 1997 processing tomato variety trial data for replicated varieties. Combined data from five locations (C olusa, F resno, San J oaquin, Sutter, and Yolo C ounties).

\begin{tabular}{|c|c|c|c|c|}
\hline Variety & $\begin{array}{c}\text { Yield } \\
\text { (tons/acre) }^{2}\end{array}$ & ${ }^{\circ}$ B rix $^{y}$ & $\begin{array}{c}{ }^{\circ} \mathrm{Brix} \times \\
\text { yield } \\
\text { (tons/acre) }\end{array}$ & $\begin{array}{c}\text { B lended } \\
\text { juice } \\
\text { colorw }\end{array}$ \\
\hline H yPack 159 & 52.1 & 4.6 & 2.39 & 23.3 \\
\hline CXD 188 & 51.3 & 5.0 & 2.56 & 21.3 \\
\hline AB 4077 & 49.9 & 5.1 & 2.55 & 21.9 \\
\hline H 8892* & 48.6 & 4.8 & 2.33 & 22.4 \\
\hline H 9492 & 48.5 & 5.0 & 2.43 & 22.2 \\
\hline Sun 6229 & 47.9 & 5.0 & 2.39 & 23.9 \\
\hline CXD 181 & 47.7 & 4.9 & 2.34 & 23.4 \\
\hline CXD 189 & 45.6 & 4.6 & 2.10 & 23.4 \\
\hline PX 6514 & 45.3 & 5.1 & 2.31 & 23.8 \\
\hline H yPeel 322 & 44.9 & 5.0 & 2.24 & 23.5 \\
\hline $\mathrm{H}$ alley $3155^{*}$ & 44.3 & 5.3 & 2.35 & 23.8 \\
\hline CXD 179 & 44.2 & 5.2 & 2.30 & 22.7 \\
\hline H MX 5887 & 43.1 & 5.1 & 2.20 & 23.3 \\
\hline H M X 487800 & 42.5 & 4.9 & 2.08 & 24.1 \\
\hline BOS 20/ 20 & 42.4 & 5.0 & 2.12 & 23.2 \\
\hline Sun 6216 & 42.3 & 4.9 & 2.07 & 22.2 \\
\hline RPT 1294 & 41.5 & 5.0 & 2.07 & 22.3 \\
\hline $\mathrm{LSD}_{0.05}$ & 2.8 & 0.2 & 0.15 & 0.9 \\
\hline CV $(\%)$ & 9.8 & 6.2 & 10.7 & 6.6 \\
\hline M ean & 46.0 & 5.0 & 2.28 & 23.0 \\
\hline Variety $\times$ location $\left(\mathrm{LSD}_{0.05}\right)$ & 6.3 & 0.4 & 0.34 & NS \\
\hline
\end{tabular}

w1 ton/ acre= $2.24 \mathrm{t} \cdot \mathrm{ha}^{-1}$

xpercent soluble solids. Composite fruit sample, mixed in a blender under vacuum.

yYield $\times{ }^{\circ}$ Brix, 1 ton/ acre $=2.24 \mathrm{t} \cdot h \mathrm{a}^{-1}$.

${ }^{\mathrm{z} C}$ omposite fruit sample, mixed in a blender under vacuum. The lower values are more intense red than larger values.

vStandard varieties.

${ }^{\mathrm{N}} \mathrm{N}$ onsignificant.

processors, seedsmen and other interested persons, are encouraged to attend and make their own observations on plant architecture, fruit maturity, fruit set and additional variables of interest.

An annual edition of the trade magazine California Tomato Grower is dedicated to research reports from U C farm advisors. This magazine reaches most of the people interested in the California processing tomato industry. The variety test conditions and results are al ways a part of this edition. Participating advisors preparea detailed report of their individual test, as well as the state summary, and mail it to their local processing tomato clientele. A summary of the statewide trials is prepared for CTRI and published in their annual report. $M$ any advisors summarize their variety results in their county newsletters, which reach additional clientele. Theadvisorsalso providethetest results at regional commodity meetings held each winter.

\section{Results and discussion}

1997 Tests. T ables 1 and 2 report the results of the 1997 early and midmaturity cultivar evaluations. They contain fruit quality and yield information for the five locations participating in the 1997 evaluations. The data has been analyzed to show differences due to both varieties and locations.

The U niform Regional Processing Tomato Variety Evaluation Program conducted by $\mathrm{U} C$ farm advisors has proven to be an effective way to test the many new releases from private seed breeders every year. It is an industry-driven effort that involves recipients from the planning through the reporting phases. The resultant information is disseminated in many ways and is used by producers and processors to make research-based intelligent varietal selection decisions.

\section{Literature cited}

California Agricultural Statistics Service. 1997. Summary of county agricultural commissioners' reports-1995/ 1996. Calif. Agr. Stat. Serv., Sacramento.

California Agricultural Statistics Service. 1998. California vegetable review: (19) 1. Calif. Agr. Stat. Serv., Sacramento.

Rivara, C.J. 1997. 1997 Annual report. Calif. Tomato Res. Inst., Escalon. 